\begin{tabular}{c} 
Volume and Issues Obtainable at Center for Sustainability Research and Consultancy \\
Journal of Business and Social Review in Emerging Economies \\
ISSN: 2519-089X (E): 2519-0326 \\
Volume 5: No. 2, December 2019 \\
CSRᄃ \\
Joournal homepage: www.publishing.globalcsrc.org/jbsee \\
\hline
\end{tabular}

\title{
The Impact of Economic Integration and Economic Growth on Environmental Degradation in South Asian Countries
}

\author{
${ }^{1}$ Huma Ilyas , ${ }^{2}$ Ayesha Zulfiqar \\ ${ }^{1}$ Lahore College for Women University, Lahore, Pakistan: huma_ilyas91@ @otmail.com \\ ${ }^{2}$ Lahore College for Women University, Lahore, Pakistan: ayeshazulfiqar1191@yahoo.com
}

\begin{tabular}{l} 
ARTICLE DETAILS \\
\hline History \\
Revised format: November 2019 \\
Available Online: December 2019
\end{tabular}

\section{Keywords}

Economic Integration, Environment, Growth, Trade liberalization, Foreign Direct Investment

JEL Classification:

F02, O47, O49, P33

\begin{abstract}
Economic integration has been acclaimed as a way to increase world output grounded on the economies of scale and the exchange of technology, ideas and information. However, it is of great concern that the impact of integration may have on the increase in threats to the environment, natural resources and human health, due to the implicit improvement in economic growth. Two main channels through which integration contributes to the growth of the literature have been identified as foreign direct investment and trade. This study explores the effects of economic integration and economic growth on environmental degradation in the years 1995 to 2015. This study was conducted using the panel data. We apply panel unit root, co-integration tests, and Pooled mean group model to examine the short and long-run relationships among economic integration, economic growth, and the environment in five Asians countries named Pakistan, India, Sri-Lanka, Bangladesh and Nepal. The results of the Pooled Mean Group Model found that there is a long-term relationship among the projected variables for the whole sample. Long run results of Pooled Mean Group model showed that economic growth and foreign direct investment have substantial and positive effect on environmental degradation while trade openness has negative but significant influence on environmental degradation. On the basis of our findings, economic integration indicates that developing countries need to formulate a sound environmental policy to improve environmental impacts on the environment. The trade-induced environmental selection effect can be controlled by creating a competitive environment in the selected regions that can be secured by focusing more on intra-industry trade.
\end{abstract}

(C) 2019 The authors, under a Creative Commons AttributionNonCommercial 4.0

Corresponding author's email address: huma_ilyas91@ @otmail.com

Recommended citation: Ilyas, H. and Zulfiqar, A., (2019). Impact of Economic Integration and Economic Growth on Environmental Degradation in South Asian Countries. Journal of Business and Social Review in Emerging Economies, 5 (2), 389-398

DOI: $10.26710 /$ jbsee.v5i2.698

\section{Introduction}

Integration has generated an emergent inter-dependence between economies as well as societies through crossborder stream of goods and services, technology, ideas, information, people and capital (Esty\&Ivanova,2004). Globalization has-been hailed as generating economic opportunities besides stimulating economic growth in 
pretentious economies. This economic growth also assumed assistance by providing essential financial resources intended for environmental safety through newly adopted environmental lawmaking that may be used as well as reinforced effectively in order to ensure sustainable development. Nevertheless, the influence of integration ought to increasing the threats to environment, resources and health of human beings, due to the implicit enhancement in economic growth. Conferring to Esty (1994), "trade liberalization would stimulate economic growth, thus aggravating environmental degradation”.

Even though economic integration exceeds trade, international trade is a key catalytic agent for growth. Trade is essential forunder-developing economies as well as for developed nations for the reason that developed economies source raw materials which are essential for ample capital from developing economies whereas developing economies provides technical knowledge and capital goods of these industrialized economies of globe.

South Asian Association for Regional Cooperation (SAARC) comprises on eight countries are characterized by relatively high population densities, low per capita income and literacy rates and the unplanned use of technology in various sectors that causes environmental degradation. Conventional wisdom is that higher economic growth requires huge cause's higher emissions and, in turn, degrades environmental pollution and threatens the sustainability of the environment. Today, climate change and global warming attracted considerable attention throughout the world.

In South Asia, winter brought some major misfortunes. The thickness of smog in some cities wreaks havoc with mobility and air traffic. This problem is the result of the burning of fossil fuels, biomass, diesel, plants, power plants and dust, and the cold winter aggravates it. According to the Meteorological Department of India and Nepal, the intensity and duration of days affected by smog have increased over the past decade. People suffer from lung and respiratory diseases. World Health Organization assessments that 2.4 million individuals decease every year due to air-pollution and 1.5 million of these deaths are because of inner air-pollution. Dhaka, capital of Bangladesh, shows an air pollution index as high as $40 \%$ reported by the BBC. Pollution is likely to increase in India over the next few years as its energy demands rise. Environmental effects such as earthquakes, floods, fire blasts and epidemics in South Asia over the last two decades have forced economists and environmentalists to seriously face the deterioration of the environment.

The relationship among economic growth (measured as Real GDP percapita) and contamination, among economic growth and openness of trade, has been investigated in depth over last two epochs. However, as economies around the globe continue to mature and progress, there is growing concern in illuminating the dynamic association between these variables.

\section{Research Questions:}

The present study investigates the impact of economic openness, economic growth and foreign direct investment on environmental quality in long run for five Asian counties. Such information would enable policy makers to make sound decisions on issues concerning economic growth and environmental protection.

\section{Objective of Study:}

Study aim to found link among economic growth, economic integration and environmental degradation by focusing on a sample of five Asians economies environment for time span 1995- 2015 with following objectives:-

- To find the impact of economic growth on environment degradation in five Asian countries

- To find the impact of economic openness and foreign direct investment on environment degradation in five Asian countries

- To estimate a long-term relationship amongCO2 emissions, GDP, and economic integration

\section{Hypotheses:}

Following are the hypothesis of this study:

Ho1: Gross Domestic Product has no significant impact on environment degradation

Ho2: Economic integration has no significant impact on environment degradation

Ho3: Gross domestic product, foreign direct investment and economic openness have no significant long-term relationship between environmental degradation 


\section{Significance of study}

Why it's interesting to study link among economic growth, economic integration and environmental degradation? The discussion emphasized on two divergent (but interrelated) concerns (Huang and Labys, 2001). The first, according to the Kyoto Protocol agenda, is upward tendency in carbon emanations. The utmost-chief challenge for environmental policy is to minimize these emissions. Second key problem is trade openness, which is likely to boost GDP growth, but can upsurge contamination.

This study critically examines the arguments in favor and in contradiction of the study of inconsistency among the upsurge in trade, investment and maintenance of ecologically-friendly development model. The study is established with a focus on two crucial lines. To achieve these goals, we will analyze a complete set of five "Asian economies, Pakistan, Sri Lanka, India,Nepal and Bangladesh" using co-integration and error correction techniques. To my best knowledge, there are only few empirical studies that targets the associations among economic growth (GDP), economic integration (FDI, Trade openness) and environmental degradation across five Asian economies, because most of the literature just focused on economic growth and environment or trade and environment but none of the study made to check influence of Trade openness, FDI and growth on e Environment specially in case of SAARC region.

\section{Literature Review}

A logical and systematic review of the literature enabled the study to evaluate the extent of to which trade liberalization and foreign direct investment (FDI) impacts in terms of growth and integration with Asian economies development. A review of results of relevant studies conducted in various countries has been presented in the following section.

During the period 1985-2000, Mexico shifted from the closed to opened economies in the world. However, this sort of economic integration had ramifications on the environment and the levels of degradation have been examined by Kevin and Gallagher (2004). This paper mainly draws on two theories of economic literature: named 'Environmental Kuznets Curve' (EKC), and 'Pollution Haven Hypothesis(PHH). Strong advocates of liberated trade when it comes to North America Free Trade Agreement (NAFTA), in the lights of EKC, argue that economic integration in countries like Mexico would lead to an improvement of the environment. On the other hand, the opponents of free trade contend that it has automatically leaded to deterioration of the environmental conditions in developing countries.

McCartney and Adamowicz (2006) depict a central theme working towards increased revenue and promotion of economic growth when discussing the potential of trade liberalization. This study is supported by two studies conducted by Grossman and Krueger $(1993 ; 1995)$ and shows the association among income per capita growth and contamination level to be upturned U-shaped curve. It is therefore assumed that an initial period of a declining economic growth in a country's environment is followed by a phase of improvement (Environmental Kuznets curve $\mathrm{EKC})$.

The purpose of paper was to declare, a verifiable opinion on reflex of liberalizations of trade on environment. The econometric models forecast this estimated effects of organic pollutants water (BOD) and carbon dioxide (CO2). Both free trade models found that quality of environment and trade are inversely proportional to each other due to an upsurge in emissions when the trade increases. However, additional observations were made by controlling undetected heterogeneity between the countries to find the influence of free-trade on environment.

The effect of international integration through investment as well as free trade in environmental protection on China for the data spanning from 1996-2004 has been studied in Zang and Eastin(2007). The conclusion reached, tied up liberalization of free trade and FDI to absolute improvement in quality of the environment when better standards and environmental technology development was encouraged in China. In addition to that, a more stringent policy with an increased trade and investment can prevent a spiral downfall with lower environmental standards.

The connection-among economic growth, international trade and environmental pollution has been examined theoretically and empirically in Abdulai and Ramcke (2009). By using the panel data for the span 1980-2003 from the developed and developing countries, several environmental factors and one sustainability indicator are analyzed for the full samples to point towards the existence of EKC for most pollutants with some reservations in place, but 
apart from modest support for Pollution Heaven Hypothesis (PHH) it still falls short of fully confirming any hypotheses drawing parallels between trade and environmental degradation.

The impact of liberalization of trade could be favorable for sustainable development in rich countries but could engender egregious problems in the poor countries. Such countries as opposed to developed countries are more vulnerable to lose health and productivity, due to lack of institutional capacities that establish appropriate policies. The results of analysis for low and high as well as regional income groups support economic growth, trade and environment but there is no unique relationship with emissions. EKC for environmental indicators is shown by income ratio and none of hypothesis showing relationship between trade and environment has been full approved.

Naranpanawa (2011) conducted the study which examined-longrun balance and short-run dynamic association between $\mathrm{CO} 2$ emissions and trade openness to Sri Lanka using the ARDL bounds test approach and Johansen and Juselius co-integration procedure within a multivariate setting. This study has included per capita real GDP and per capita real gross fixed capital formation such as additional variables in the multivariate framework. Even though the study has been found to have a longrun equilibrium association between the variables with no the longterm causality flanked by openness of trade and $\mathrm{CO} 2$ emissions, there seems to be a shortrun unidirectional causality consecutively from trade openness to decrease $\mathrm{CO} 2$ emissions, inferring that the rise in trade would lift $\mathrm{CO} 2$ emissions in the short. The paper also found short-term causality moving from trade openness towards real GDP and real GDP for capital. Moreover, there seems to be a two-way Granger causality between trade openness and capital.

Xuan Wang (2011) paper focused on quick economic integration due to the more globalization has two different influences: on one side, it increases productivity and contributes to economic growth; but on the other side, it worsens the environmental conditions and leads a severe environmental degradation problem. Economic prosperities are developing under the traditional GDP or GNP measurement; however, the real human welfare cannot be ascertained as really increasing, when taking the negative externalities into account. This paper tests the effect of openness to international trade at Chinese provincial level, by applying Comparable Green GDP data from 31 provinces and regions to a variant of Solow growth model. The main finding is: there exists a non-linear relationship between green GDP and openness, measured both by volume of trade and foreign directly investment (FDI), at provincial level. Spontaneously, openness has an inverted U shape effect: it increases sustainable development at the beginning and decreases sustainable development after a threshold point. This result accords with the finding by Talberth\&Bohara (2006) at national level.

Cialani (2013) examined the relationship between emissions CO2per capita, international trade and GDP per person founded on panel data covering the time 1960-2008: for hundred and fifty countries and others following the example of OECD and non-OECD countries. This paper applied panel unit root and co integration tests, and estimated a error correction model. The outcomes suggested that there were short term bidirectional causality relationship between growth and openness, together with a causal link among $\mathrm{CO} 2$ emissions plus economic growth and free trade, the entire sample. These outcomes recommend that growth policies, trade and environmental pollution must address instantaneously.

Avazalipouret al. (2013) find out the association-among foreign direct investment, the quality of environment. For research purpose they, first select some countries, non-OECD nations, panel data was used for the time span 19962007. Fixed effect model is used to check the relationship among FDI also in chemical pollution. The results show that increasing the FDI flow in non-OECD, the increase in FDI can make the water contamination. In other words, foreign direct investment in non-OECD countries is causing environmental problems (Selected Countries).

\section{Methodology and Data Sources}

This part depicts the informational index and approach utilized in the experimental investigations, and furthermore gives the defense to the determination of factors. The variables are designated Economic Growth (GDP), Trade Openness and FDI on the Carbon dioxide release in the South Asian countries like Pakistan, Nepal, Bangladesh, India, Sri-Lanka, and Nepal.The selected countries are developing economies and characterized by relatively high population densities, low per capita income and literacy rates and the unplanned use of technology in various sectors that causes environmental degradation. Environmental effects such as earthquakes, floods, fire blasts and 
epidemics in South Asia over the last two decades have forced economists and environmentalists to seriously face the deterioration of the environment. In the study secondary data is used for the time spam of 1995 to 2015.

\subsection{Model Specification}

The general econometric model is given below:

$$
\text { LCO } 2 \text { it }=\beta 0+\beta 1(\text { LGDPit })+\beta 2(\text { LTOit })+\beta 3(\text { FDIit })+\text { eit }
$$

Where: LCo2 is the Log of CO2 emissions, LGDP is Log of GDP per capita, LTO is the Log of Trade Openness, FDI is Foreign Direct Investment, $i$ are the countries in the panel, $t$ is for time period (1995-2015) and $\beta 1, \beta 2, \beta 3$ are Coefficients $(\beta>/<0, \beta>/<0, \beta>/<0)$

\subsection{Methodology}

The panel data econometric methodology known as Pooled mean group (PMG) is applied; this study examined the long run and short run association between independent variables and environmental degradation for economies five Asian economies.

\subsection{Data Sources}

The variables CO2 emission, Foreign Direct Investment (FDI) Growth variable GDP for all sample countries is taken from World Development Index. Economic openness is taken from WDI source and calculated as export of goods and service plus import of goods and services as a share of Gross domestic product.

\section{Results and Analysis}

This study encompass of four variables environmental degradation, economic growth, economic integration (i.e. Trade openness and FDI). Whereas, net results presents in succeeding Section, Descriptive statistics, Panel Unit root test, Johansen Fisher Panel Cointegration Test, Pooled mean group

\subsection{Panel Unit Root Stationary Tests}

The table in the end provided represents the consequence of successions sationarity, the present study used some same unit tests (LLC, IMP,ADF and PP) to satisfy the variables are non-stationary or stationary . Bestowing to Levin et al. (2002), the null hypothesis of LLC is a unitary root. It is essential to check the saturation of variables as non-stationary variables can cause wrong outcomes

The results show that variables are tested at first level with intercept proceeding the basis of LLC IMP,ADF and PP and no variable is attain stationary, when variables are tested at first difference, all variables are stationary at order one 1(I), thus, altogether variables on the basis of all tests were stopped at 1 (I). So we can now continue check cointegration, whether variables have long run association or not.

\subsection{Johansen Fisher Panel Cointegration}

Johansen (1988) put forward two altered methodologies, one is the probability ratio statistics and the other is maximum eigen-value statistics, for the existence of cointegration vectors in non-stationary time series.

\section{Johansen Fisher Panel Cointegration}

\begin{tabular}{|l|l|l|l|l|}
\hline $\begin{array}{l}\text { Hypothesized No of } \\
\text { CE(s }\end{array}$ & $\begin{array}{l}\text { Fisher Stat.* } \\
\text { (from trace test) }\end{array}$ & Prob. & $\begin{array}{l}\text { Fisher Stat.* } \\
\text { (from,max-eigen test) }\end{array}$ & Prob. \\
\hline None & 77.75 & 0.0000 & 40.75 & 0.0000 \\
\hline At most 1 & 46.75 & 0.0000 & 28.67 & 0.0014 \\
\hline At most 2 & 0.0021 & 23.95 & 0.0077 \\
\hline At most 3 & 0.1689 & 14.09 & 0.1689 \\
\hline \multicolumn{4}{|l|}{ Null hypothesis: There is no co integration } \\
\hline
\end{tabular}

Above table shows results of co-integration among the proposed variables, because all the variables found stable at the first difference, at present the subsequent step is to analyses if co-integration exists or no. The current study used a johansen fisher co-integration test that is consisting of two kinds of test one is trace and other one is maxegien test. The result of a cointegration test recommended two co-integration equation based on the trace test and two co-integration equations based on the max-eigen test. Consequently, we reject the null hypothesis of no cointegration and accept the alternative hypothesis that is there is a cointegration. So co-integration indicates the longterm link between the proposed variables (that is, variables move Long-term set). 


\subsection{Pooled Mean Group Long Run Estimators}

The PMG estimator is based on a mixture of amalgamation and mean coefficients (Pesaranet al., 1997, 1999). This estimator allows the short-run parameters; the intercept term and the variance of the errors vary according to the groups (as in the MG estimator). However, it prevents the long-term coefficients from being equivalent. From the primary estimate of the long-term coefficient, we can find the short- run coefficients and the error correction term. These estimates are used, in turn, to estimate $\theta$, the process is iterated until the convergence is reached. PMG appears to be more suitable technique for estimation in present circumstances. Long run results are given in table

\subsection{Pooled Mean Group long run estimators}

\begin{tabular}{|l|l|l|l|l|}
\hline Variables & Coefficients & Std. Error & t-statistics & p-value \\
\hline GDP & 0.464617 & 0.217949 & 2.131769 & 0.0001 \\
\hline TO & -0.590717 & 0.214882 & -2.749029 & 0.0000 \\
\hline FDI & 0.228718 & 0.071332 & 3.206387 & 0.0313 \\
\hline
\end{tabular}

In this model the Gross domestic product per capita (GDP) on Environmental degradation (CO2) conforms to economic theory. Long run results of PMG model shows that GDP have significant and positive influence on environmental degradation, in selected Asian Economies as p-value (0.0001) is less than $\alpha(0.05)$. One percent upsurge in GDP will increase environmental degradation by 0.46 percent. Uddin and Wadud scrutinized the causal link among carbon emissions and Economic growth in seven SAARC economies via historical data for the period 1972 to 2012; results present a co-integration association among environmental contamination and economic growth. Also demonstrate that estimated emission coefficients have positive and substantial impacts on GDP.

Trade openness has significant and negatively related with the Environmental degradation. The p-value $(0.000)$ is less than $\alpha(0.05)$. One percent rise in Trade openness will decrease degradation of environmentupto-0.59 percent. Taylor et al. (2001) and Azharet al. (2007) and Tariq \&Ab (2016) also found the negative impact of trade openness on environmental degradation. The industry-induced environmental selection effect shows that, due to competition with the number of enterprises opening companies' decreases, this decrease in the number of companies has a positive impact on the environment. Taylor et al. (2001) and Azharet al. (2007) support the claim that the effect of trade-induced environmental technology is environmentally friendly. A strong empirical indication, from the analysis, supports the assumptions postulated by the theory that $\mathrm{CO} 2$ emission levels increase due to the effect of the environmental technique, while decreasing due to the effect of the trade-induced environmental technique. The increase in trade intensity / trade opening is beneficial to the quality of the environment.

Furthermore FDI is also significant and positively related with environmental degradation. The p-value is $(0.03)$ is less than $\alpha(0.05)$. One percent rise in FDI will increase degradation of environment by means of 0.22 percent. The theoretical concerns of the environmental effect of FDI in developing countries, called the FDI-environment link or nexus (e.g.Pethig 1976, Porter\&Linde 1995, Copeland\&Taylor 1994; 1995,) postulate that FDI has a positive relationship with environmental degradation.

\subsection{Short Run Estimates Of Poole Mean Group Model}

After getting the long run estimates of PMG estimator, the below mentioned ECM is applied to evaluate the short run estimates:

Pooled Mean Group Short run estimators

\begin{tabular}{|l|l|l|l|l|}
\hline Regressors & Coefficient & Standard Errors & t-ratios & Probability \\
\hline COINTEQ01 & -0.925776 & 0.325568 & -2.843572 & $0.0112^{*}$ \\
\hline $\mathrm{D}(\mathrm{CO} 2(-1))$ & 0.518776 & 0.194429 & 2.668199 & $0.0162^{*}$ \\
\hline $\mathrm{D}(\mathrm{CO} 2(-2))$ & 0.896407 & 0.671092 & 1.335744 & 0.1992 \\
\hline $\mathrm{D}(\mathrm{CO} 2(-3))$ & -0.038042 & 0.447541 & -0.085002 & 0.9333 \\
\hline $\mathrm{D}(\mathrm{GDP})$ & 1.380643 & 4.056553 & 0.340349 & 0.7378 \\
\hline $\mathrm{D}(\mathrm{GDP}(-1))$ & 3.028498 & 4.735139 & 0.639580 & 0.5310 \\
\hline $\mathrm{D}(\mathrm{GDP}(-2))$ & 2.575460 & 4.742300 & 0.543082 & 0.5941 \\
\hline
\end{tabular}




\begin{tabular}{|l|l|l|l|l|}
\hline $\mathrm{D}(\mathrm{GDP}(-3))$ & 0.914322 & 1.186192 & 0.770805 & 0.4514 \\
\hline $\mathrm{D}(\mathrm{TO})$ & 1.399493 & 0.547044 & 2.558283 & $0.0204^{* *}$ \\
\hline $\mathrm{D}(\mathrm{TO}(-1))$ & 1.086398 & 0.588447 & 1.846211 & $0.0823^{*}$ \\
\hline $\mathrm{D}(\mathrm{TO}(-2))$ & -0.606900 & 0.194934 & -3.113364 & $0.003^{* *}$ \\
\hline $\mathrm{D}(\mathrm{TO}(-3))$ & -0.010446 & 0.362554 & -0.028812 & 0.9774 \\
\hline $\mathrm{D}($ FDI $)$ & 0.240175 & 0.229574 & 1.046178 & 0.3101 \\
\hline $\mathrm{D}($ FDI $(-1))$ & -0.025400 & 0.211416 & -0.120140 & 0.9058 \\
\hline $\mathrm{D}($ FD-2) $)$ & 0.395576 & 0.251716 & 1.571514 & 0.1345 \\
\hline $\mathrm{D}($ FDI $(-3))$ & 0.115465 & 0.054732 & 2.109656 & $0.0500^{* *}$ \\
\hline $\mathrm{C}$ & -8.622939 & 3.072286 & -2.806685 & $0.0121^{*}$ \\
\hline
\end{tabular}

As shown in the Table, the coefficient of Error Correction Mechanism (ECM) is statistically significant (-0.92) suggesting a convergence to the equilibrium path, the error correction process converges 92 percent equilibrium path in a year. The magnitude of ECM coefficient implies that nearly $92 \%$ of any disequilibrium in the environmental degradation (CO2) is corrected by the exogenous variables within one period (one year).

The significance and the correct sign of the error correction coefficient as per suggested by theory also approve the existence of a longrun equilibrium association among economic growth and independent variables included in the model.

The economic growth devours positive but insignificant effect on environmental degradation in five Asian economies. The coefficients of GDP at year t-1, t-2 and $\mathrm{t}-3$ are statistically insignificant but positive in short run.

The coefficient of the Trade openness at the year $\mathrm{t}$ is positive and substantial in the shortrun analysis. The first lag is positive but insignificant at year t-1. The second lag is showing negative but significant relationship of trade openness with environmental degradation. The coefficient of TO at year t-3 is statistically insignificant and negative in short run analysis.

The FDI coefficient has positive and economically insignificant impact on environmental degradation at year $t, t-2$ but it has negative and insignificant impact on economic growth at the year t-2. While at year $\mathrm{t}-3$ it is positive and significant. So all the variables such as economic growth and economic integration have ambiguous effect on environmental degradation at different lags in short run.

\section{Conclusion and Recommendations}

In this study, we inspect cointegration, long-run and short run relationship among projected variables such as environmental degradation, economic growth and economic integration build on cross country panel data set covering five Asian economies taken as, Pakistan, Sri-Lanka,India, Nepal and Bangladesh during the period 19952015. This study is of panel data nature, for the time 1995-2015. The study at palm, collected annual data from World Development Indicator. The study purposed environmental degradation as dependent variable while economic growth and economic integration as independent variables.

By applying unit root test, we originate that all three succession the logarithm of per capita GDP, per kg CO2 emissions and openness and foreign direct investment follow I(1) processes. These outcomes were at that moment used to apply Pooled mean group test. The p-values acquired from both Johnson fisher cointegration test and groupmean test shown that null hypothesis of no cointegration would be spurn for the sample of all five economies. This advocates that CO2 emissions, GDP per capita, openness of trade and FDI are cointegrated. Subsequently, there were long-run equilibrium associations between these four variables. Our outcomes are reliable with preceding results done by different researchers as conferred in literature review.

Long run results of PMG model demonstrate that, economic growth retains significant and positive influence on environmental degradation, in selected five Asian Economies. The rise in GDP will increase environmental degradation by dint of 46 percent.

Trade openness has significant and negatively related with the Environmental degradation. An increase in Trade openness will decrease Environmental degradation by 59 percent. The result of this study is very much similar with the work of Taylor et al. (2001) and Azhar et al. (2007) andBilal Tariq \&RossazanaAb (2016). 
Furthermore foreign direct investment is also significant and positively related with Environmental degradation. One percent increase in foreign direct investment will increase Environmental degradation by 22 percent. The theoretical concerns of environmental effect of FDI in developing economies, called the FDI-environment link or nexus "(e.g.Pethig 1976, Copeland \& Taylor 1994 to 1995, Porter \&Van der Linde 1995)" postulate that FDI has a positive relationship with environmental degradation.

The sign and magnitude of the coefficient of the error correction mechanism (ECM) determine a short run adjustment process. The coefficient of ECM is statistically significant (-0.92) suggesting a convergence to the equilibrium path, the error correction process converges 92 percent equilibrium path in a year. In this study, the negative value of the ECM coefficient (-0.925) confirms that there is disequilibrium in the shortrun which set of variables in model are trying to correct in the long-run. The magnitude of ECM coefficient implies that nearly $92 \%$ of any disequilibrium in the environmental degradation $(\mathrm{CO} 2)$ is corrected by the exogenous variables within one period (one year).

The significance and the correct sign of the error correction coefficient as per suggested by theory also ratify the existence of long run equilibrium association among economic growth and independent variables included in model.

So all of the factors such for instance GDP per capita, Trade Openness as well as FDI have ambiguous effects at different lags in short run. The estimator allows the short-run parameters; the intercept terms and the variance of the errors vary according to the groups. So the short run coefficients results vary according to the situation and policy rules among each country.

On the basis of our findings, economic integration indicates that developing countries need to formulate a sound environmental policy to improve environmental impacts on the environment. Additionally, they requisite comply with strict environmental impacts to evadetoo much pollution, arbitrary deforestation, exploitation of marine resources and unambiguous property privileges. The trade-induced environmental selection effect can be controlled by creating a competitive environment in the selected regions that can be secured by focusing more on intraindustry trade. In addition, the hazardous effects of intra-industry trade can be eliminated by investing more in green technology and research and development. The production rate is a major source of $\mathrm{CO} 2$ emissions. Therefore, it is recommended to achieve production capacity through the application of the technology, which may reduce the level of contamination.

On the base of conclusion of the present research study this area can be more probes in various ways as follows. First, present study uses four macroeconomic variables, academicians and researchers should include other different and more variables and can investigate other important factors which can accurately predict environmental degradation. Second, the study focused only five SAARC economies, while this research can be done by considering more Asian economies. Third, other research can consider structural breaks as well while modeling Environmental degradation.

\section{References}

Azhar, U., Khalil, S., \& Ahmed, M. H. (2007). Environmental effects of trade liberalisation: a case study of Pakistan. The Pakistan Development Review, 645-655.

Avazalipour, M. S., Zandi, F., Saberi, R., Hakimipour, N., \&Damankeshideh, M. (2013)The Impact of FDI on Environmental Resources in Selected (NonOECD).www.arpapress.com/Volumes/Vol17Issue1/IJRRAS_17_1_13.pdf

Cialani(2013). CO2 emissions, GDP and trade: a panel cointegration approach. International Journal of Sustainable Development \& World Ecology, 193-204.

Kevin P. Gallagher(2004). Economic Integration and the Environment in Mexico: Lessons for Future Trade Agreements. The Working Group on Development and Environment in the Americas, Paper 6

Mohan, R. (2007). A panel data analysis of FDI, Trade Openness, and Liberalization on Economic Growth of the ASEAN-5. The Empirical Economic Letters, 6(1), 120-219.

McCarney, G. R., \&Adamowicz, W. L. (2005). The effects of trade liberalization on the environment: an empirical study. In Annual Meeting, July 6-8, 2005, San Francisco, CA (No. 34157). Canadian Agricultural Economics Society. 
Naranpanawa, A. (2011). Does trade openness promote carbon emissions? Empirical evidence from Sri Lanka. The Empirical Economics Letters, 10(10), 973-986.

Wang, X.,(2011). Green GDP and Openness: Evidence from Chinese Provincial Comparable Green GDP.Journal of Cambridge Studies, 6(1), 103-118. 


\section{Panel unit root test}

Table: 4.1

\begin{tabular}{|c|c|c|c|c|c|}
\hline Variables & Levin, Lin \& Chu t* & $\begin{array}{c}\text { Im, Pesaran and Shin } \\
\text { W-stat }\end{array}$ & ADF-Fisher-Chi square & PP - Fisher Chi square & Decision \\
\hline & $\begin{array}{c}\text { t-statistics p-value } \\
\text { level }\end{array}$ & $\begin{array}{c}\text { t-statistics } p \text {-value } \\
\text { level }\end{array}$ & $\begin{array}{c}\text { t-statistics p-value } \\
\text { level }\end{array}$ & $\begin{array}{c}\text { t-statistics p-value } \\
\text { level }\end{array}$ & \\
\hline $\mathrm{LCO}_{2}$ & $6.314 \quad 1.000$ & $2.180 \quad 0.983$ & $7.292 \quad 0.697$ & 1.165 & $\mathrm{I}(1)$ \\
\hline $1^{\text {st }}$ difference & $-1.299 \quad 0.096$ & $\begin{array}{ll}-1.987 & 0.023\end{array}$ & $24.38 \quad 0.006$ & 28.87 & \\
\hline LGDP & $3.151 \quad 0.999$ & 1.000 & $0.178 \quad 1.000$ & 0.138 & $\mathrm{I}(1)$ \\
\hline $1^{\text {st }}$ difference & $-3.448 \quad 0.000$ & 0.000 & 0.000 & 0.000 & \\
\hline LTO & -1.556 & -1.922 & 29.03 & 33.90 & $\mathrm{I}(1)$ \\
\hline $1^{\text {st }}$ difference & $-6.173 \quad 0.000$ & -7.997 & 72.06 & 0.000 & \\
\hline FDI & $\begin{array}{ll}-0.517 & 0.302\end{array}$ & 0.676 & $4.946 \quad 0.894$ & 4.615 & $\mathrm{I}(1)$ \\
\hline $1^{\text {st }}$ difference & -7.479 & -6.209 & 51.94 & 52.83 & \\
\hline
\end{tabular}

